"Przegląd Prawa Konstytucyjnego"

----- ISSN 2082-1212 ------

DOI 10.15804/ppk.2014.04.11

Nr $4(20) / 2014$

\title{
Sprawozdanie
}

\section{Obchody Światowego Dnia Wyborów, Warszawa, 6 lutego 2014 r.}

W pierwszy czwartek lutego obchodzony był Światowy Dzień Wyborów. Tradycyjnym punktem obchodów był wykład im. Prof. Wacława Komarnickiego organizowany przez Centrum Studiów Wyborczych Uniwersytetu Mikołaja Kopernika w Toruniu wspólnie z Państwową Komisją Wyborczą. W dniu 6 lutego 2014 r. w Rezydencji Belweder-Klonowa w Warszawie prelekcję wygłosił dr hab. Piotr Uziębło z Uniwersytetu Gdańskiego. Tematem referatu były Cenzusy wyborcze w XXI w. - potrzeba nowego podejścia?

Pytanie sformułowane w tytule wykładu skłania do refleksji nad potrzebą pomyślenia o konieczności nowego nakreślenia pożądanego kształtu ograniczeń praw wyborczych. Referent wskazywał na procesy globalizacyjne, częste przemieszczanie się osób, mieszanie się społeczności czy tworzenie społeczeństw informacyjnych. W treści wykładu zostało przyjęte szerokie rozumienie pojęcia cenzusu. Zdaniem referenta aspekt faktycznej więzi cenzusu obywatelstwa stopniowo traci na znaczeniu. Wskazują na to przykłady posiadania podwójnego czy wielokrotnego obywatelstwa skutkujące emigracją zarobkową czy tworzeniem się małżeństw lub nieformalnych związków obywateli różnych państw. Rodzi się pytanie o przyjęcie kryterium pozwalającego na korzystanie z praw wyborczych. Zdaniem referenta można mówić o występowaniu cenzusu zamieszkania. Tak będzie w przypadku przyznania praw wyborczych obywatelom Unii Europejskiej w wyborach do Parlamentu Europejskiego i do organów stanowiących samorządu terytorialnego stopnia podstawowego. Może to świadczyć o zmniejszającym się znaczeniu obywatelstwa w tradycyjnym jego rozumieniu i o silniej- 
szym wpływie na losy wspólnoty osób bez obywatelstwa państwa zamieszkania. Zdaniem prelegenta przyjęcie koncepcji efektywnego obywatelstwa rodzi problemy związane z określeniem rzeczywistego miejsca koncentracji czynności życiowych poszczególnych osób. Mówca zwrócił uwagę także na potrzebę nowego podejścia względem rozumienia cenzusu majątkowego. Jego zdaniem pozbawienie prawa wyborczego osób, które swoje podatki odprowadzają za granicą, nie stałoby w sprzeczności z zadaniami realizowanymi przez organy państwowe czy samorządowe pochodzące $\mathrm{z}$ wyborów. Jednakże takie pozbawienie praw wyborczych miałoby charakter czasowy, przez okres płacenia ich za granicą. Następnie prelegent odniósł się do tendencji obniżania wieku, którego ukończenie warunkuje nabycie praw wyborczych. Powodem tego trendu może być łatwiejszy dostęp do informacji politycznej, uwarunkowany powszechnością Internetu. Jednak zdaniem referenta poziom samodzielności życiowej zwiększa świadomość podejmowania decyzji politycznych. Przyczyny obniżenia wieku wyborczego mogą tkwić w chęci poszerzenia realizacji zasady powszechności, zwiększeniu frekwencji wyborczej czy zapewnieniu sukcesu wyborczego danej partii politycznej. Także proces starzenia się społeczeństw wskazuje na potrzebę obniżenia cenzusu wieku. Prelegent zapytał o granicę obniżania wieku uprawniającego do decydowania o losach gminy czy kraju. Procesy demograficzne są przesłanką pomysłu całkowitego zniesienia cenzusu wieku. Mówca nawiązał do koncepcji rodzicielskiego prawa wyborczego i problematyki wykonywania prawa głosowania za niepełnoletnie dzieci. Zamysł ten miałby na celu wzmocnienie siły głosu młodych wyborców. Jednak budzi szereg wątpliwości, np. z punktu widzenia zasady równości wyborów, tajności głosowania czy kwestii praktycznego wykonywania praw wyborczych nieparzystej liczby dzieci. Referent przywołał przykład Iranu jako państwa, w którym niegdyś obniżono dolną granicę czynnego prawa wyborczego do 15. roku życia. Jednak na skutek wielu przypadków odstępowania karty do głosowania innym osobom, przywrócono wymóg ukończenia 18 lat. Następnie mówca rozważał ewentualną niedemokratyczność cenzusu wykształcenia. Zdaniem prelegenta nie można mówić o wprowadzeniu takiego cenzusu w odniesieniu do czynnego prawa wyborczego. Inaczej będzie w odniesieniu do prawa biernego. Jak zauważył referent, nie każde wykształcenie wyższe daje wiedzę potrzebną w zakresie działalności 
publicznej danej osoby. Pojawiają się propozycje wprowadzenia specjalnych egzaminów weryfikujących wiedzę kandydatów na tematy związane ze stanowiskiem, o jakie ubiegają się w głosowaniu. Mówca przywołał przykład Tajwanu jako państwa, w którym odbywają się egzaminy dla osób pełniących władzę publiczną, za wyjątkiem wybranych w głosowaniu powszechnym. Prelegent skonstatował, że nie jest zwolennikiem wprowadzenia specjalnego egzaminu dla kandydatów w wyborach. Albowiem w odniesieniu do podmiotów wyłanianych w wyborach powszechnych to wyborcy oceniają, czy dana osoba posiada kwalifikacje do sprawowania danego mandatu. Ponadto należy spojrzeć na ten cenzus przez pryzmat funkcjonowania demokracji w warunkach danego państwa. Nie zawsze wykształcenie wyższe warunkuje większą świadomość polityczno-prawną.

Pan dr hab. Piotr Uziębło jest zwolennikiem wprowadzenia cenzusu zawodowego $\mathrm{w}$ odniesieniu do biernego prawa wyborczego w przypadkach, w których Konstytucja stanowi o zakazie sprawowania mandatu przedstawicielskiego. Dla przykładu, postrzeganie społeczne sędziego czy prokuratora, który kandydowałby w wyborach i przegrałby w głosowaniu, mogłoby pozbawiać jego zawodową działalność przymiotu niezależności, wymaganej w tej profesji. Zdaniem prelegenta idea cenzusu zawodowego nie ma na celu dyskryminacji pewnych grup zawodowych, a jedynie ograniczenie ich praw politycznych z uwagi na wymaganą apolityczność. Natomiast wprowadzenie cenzusu zawodowego w odniesieniu do czynnego prawa wyborczego jest w opinii referenta wątpliwe z punktu widzenia standardów demokratycznych. Szeroko rozumiana apolityczność mogłaby wkraczać w sferę wolności sumienia.

Prelegent zwrócił uwagę na to, że z cenzusem zdolności psychicznej wiąże się pewien groźny automatyzm. Można zasadnie zadać pytanie o to, czy polska instytucja cywilnego ubezwłasnowolnienia zbyt pochopnie nie wyklucza takiej osoby ze sfery życia publicznego. Mówca zauważył, że pozbawienie praw wyborczych w polskim prawie ma charakter sankcji względem ubezwłasnowolnionego. W związku z tym postuluje rozważenie możliwości wprowadzenia osobnego postępowania sądowego w sprawie o pozbawienie praw wyborczych, odrębnie dla czynnego i biernego prawa wyborczego. Poza tym istnieje cała grupa osób, które nie są ubezwłasnowolnione a same nie mają zdolności dokonania samodzielnego wyboru. Zdaniem referenta cen- 
zus penalny, powodujący automatyczne pozbawienie prawa wyborczego osób skazanych, szczególnie za przestępstwa nieumyślne, budzi poważne wątpliwości. Także i w tej kwestii to sądy powinny oceniać, czy pobudki dokonania czynu zabronionego zasługują na pozbawienie jego sprawcy praw wyborczych.

$\mathrm{Na}$ koniec swojego wystąpienia prelegent stwierdził, iż utrzymanie status quo w kwestii cenzusów wyborczych może spowodować sytuację, w której wybierać będą ludzie niemający obywatelstwa danego państwa. Tymczasem wybory muszą nadążać za rzeczywistością, aby odzwierciedlać potrzeby społeczne.

Po referacie wywiązała się dyskusja. Jako pierwszy głos zabrał prof. Andrzej Rzepliński, Prezes Trybunału Konstytucyjnego, zwracając uwagę na kwestie transgraniczności i miejsca wykonywania prawa wyborczego osób zamieszkujących tereny pograniczne. Nie zabrakło także pytania o to, czy więźniom powinny przysługiwać prawa wyborcze. Prof. A. Rzepliński odwołał się do Konwencji Bioetycznej, zakazującej więźniom uczestniczenia w eksperymencie medycznym. Zauważył przy tym, iż głosujący więzień podejmuje decyzję za siebie i za innych, wpływając na wynik głosowania. Ponadto Prezes Trybunału Konstytucyjnego indagował o to, czy parytety nie są formą wprowadzania cenzusów i czy w istocie to sami obywatele nie ograniczają swojego wpływu na sprawowanie władzy.

Do wystąpienia pytającego odniósł się dr. hab. P. Uziębło, zdaniem którego należy brać pod uwagę fakt zamieszkiwania. $\mathrm{W}$ jego opinii miejsce wykonywania pracy nie jest dostatecznym powodem uzasadniającym przyznanie praw wyborczych. Wyraził przy tym przekonanie, iż wyborcy są racjonalni na tyle, aby samemu zadecydować, kogo wybrać. Prelegent nie jest zwolennikiem automatycznego pozbawiania więźniów możliwości głosowania.

Jako drugi głos w dyskusji zabrał prof. Krzysztof Skotnicki, zwracając uwagę, iż zasada powszechności prawa wyborczego jest dynamiczna, a cenzus wykształcenia został wprowadzony na przełomie XIX i XX w. w południowych stanach Stanów Zjednoczonych Ameryki Północnej. Następnie, odnosząc się do cenzusu obywatelstwa, przypomniał, że na początku lat 90. XX w. postulowano w Polsce wprowadzenie zakazu głosowania obywateli polskich przebywających poza granicami kraju. Kolejnym zagadnieniem, na które zwrócił uwagę prof. Skotnicki, był fakt posiadania co najmniej dwóch 
miejsc zamieszkania. Poddał pod dyskusję propozycję przyznania praw wyborczych w wyborach samorządowych jedynie osobom wykazującym jakąkolwiek więź z daną gminą. Prof. K. Skotnicki zauważył, iż ławnikiem może zostać ktoś, kto spełnia warunek prowadzenia działalności gospodarczej, niekoniecznie zaś miejsca zamieszkania. Zdaniem dr. hab. P. Uziębło samo zatrudnienie nie stanowi dostatecznego powodu przyznania praw wyborczych wykonywanych na obszarze danej miejscowości.

Kolejny głos w dyskusji zabrała prof. Maria Kruk-Jarosz, zgłaszając uwagę dotyczącą tego, czy mówiąc o cenzusach, należy mieć na myśli pozbawienie prawa wyborczego, czy też nietworzenie obwodu głosowania dla pewnej grupy osób. W odpowiedzi na tę uwagę dr hab. P. Uziębło raz jeszcze wyraził swój sceptycyzm co do pozbawiania praw wyborczych $\mathrm{z}$ uwagi na samo skazanie.

Następnie w dyskusji wziął udział sędzia Stanisław Zabłocki, członek Państwowej Komisji Wyborczej. Zdaniem Pana sędziego nieutworzenie obwodów byłoby techniką manipulacyjną. Dyskutant wyraził swoją dezaprobatę dla cenzusu więźnia, zwracając przy tym uwagę na to, że cenzusy mają charakter polityczny. W opinii mówcy taką samą naturę ma frekwencja wyborcza. Odnosząc się do ostatniego zagadnienia, dr hab. P. Uziębło stwierdził, iż frekwencja nie jest celem samym w sobie i przyświeca jej cel polityczny.

Kolejny dyskutant, prof. Andrzej Mączyński, członek Państwowej Komisji Wyborczej, stwierdził, że nie należy bagatelizować rodzinnego prawa wyborczego, ponieważ wydłuża się długość życia ludzi. Ponadto koreferent wyraził wątpliwość, czy ubezwłasnowolniony może wpływać na sprawy publiczne, skoro nie jest w stanie kierować swoim postępowaniem.

Dyskusję zamknął głos doc. dr. Ryszarda Piotrowskiego, pytającego, czy $\mathrm{w}$ istocie nie istnieje cenzus afiliacji partyjnej? Być może sukces wyborczy gwarantuje założenie własnej partii politycznej czy utożsamianie się z daną partią. Może to prowadzić do deformacji systemu demokratycznego. To system alienacji wyborczej stwarzający alternatywę - albo ktoś będzie głosować na partie progowe, albo zostanie pozbawiony afiliacji politycznej.

Długa i żywa dyskusja, jaka miała miejsce po referacie, dowodzi, że pytanie sformułowane w tytule wykładu porusza kwestie ważne i aktualne. Teoretyczne rozważania miałyby wpływ na praktykę. Tematyka ta wprost od- 
nosi się do przyznawania oraz wykonywania praw wyborczych przez osoby, które już je posiadają. Zagadnienie kręgu osób uprawnionych do głosowania $\mathrm{w}$ wyborach jest kwestią doniosłą z uwagi na polityczny charakter praw wyborczych jednostki.

Radosław Zych

Uniwersytet Mikołaja Kopernika w Toruniu 